\title{
HUBUNGAN PENGETAHUAN IBU, POLA PEMBERIAN MAKAN, DAN PENDAPATAN KELUARGA TERHADAP STATUS GIZI ANAK DIBAWAH LIMA TAHUN: PENERAPAN HEALTH BELIEF MODEL
}

\author{
Sodikin $^{1}$, Suryo Endiyono ${ }^{2}$, Fitria Rahmawati ${ }^{3}$ \\ ${ }^{1}$ Lecturer Faculty of Health Sciences, Muhammadiyah University of Purwokerto \\ ${ }^{2}$ Lecturer Postgraduate Program of Sebelas Maret State University, Surakarta \\ ${ }^{3}$ Student Faculty of Health Sciences, Muhammadiyah University of Purwokerto. \\ sodikin@ump.ac.id
}

\begin{abstract}
Abstrak
Masalah status gizi balita di Indonesia cukup memprihatinkan. Faktor predisposisi yang menjadi penyebab masalah ini masih sangat sedikit diketahui. Pendekatan teori Health Belief Model (HBM) diharapkan dapat menjelaskan faktor-faktor orangtua yang berhubungan dengan status gizi anak usia dibawah lima tahun. Tujuan penelitian ini adalah untuk Mengetahui hubungan pengetahuan ibu, pola pemberian makan, dan pendapatan keluarga terhadap status gizi anak usia di bawah lima tahun. Metode penelitian yang digunakan adalah metode kuantitatif dengan desain penelitian cross sectional. Populasi dan sampel dalam penelitian ini berjumlah 189 responden dan sampel berjumlah 65 responden dengan teknik simple random sampling. Analisis data menggunakan uji chi-square. Hasil penelitian menunjukkan bahwa variabel persepsi kerentanan yang dirasakan (perceived susceptibility) yang berhubungan dengan status gizi anak di bawah usia lima tahun yaitu pengetahuan $(\mathrm{p}=0.034)$, pola pemberian makan $(\mathrm{p}=0.008)$, dan pendapatan keluarga $(p$ $=0.004$ ). Penelitian ini menyimpulkan bahwa terdapat hubungan persepsi kerentanan yang dirasakan (perceived susceptibility) yaitu pengetahuan, pola pemberian makan dan pendapatan keluarga dengan status gizi anak usia di bawah lima tahun.
\end{abstract}

Kata Kunci: pendapatan keluarga; pengetahuan ibu; pola pemberian makan; status gizi anak Balita

\begin{abstract}
The problem of nutritional status of children in Indonesia is quite alarming. The predisposing factors of the problem still very few are known. The Health Belief Model (HBM) theory approach is expected to explain parental factors related to the nutritional status of children under five years old. The purpose of this study was to determine the correlation of mother's knowledge, feeding patterns, and family income on the nutritional status of children under five years old. The research method used was a quantitative method with cross sectional research design. The population of study was 189 respondents and 65 respondents of sample with a sample technique was simple random sampling. Data analysis was using chi-square test. The results showed that perceived susceptibility was related to the nutritional status of children under five years old, including knowledge $(p=0.034)$, feeding pattern $(p=0.008)$, and family income $(p=0.004)$. This study concluded that there was a relationship between perceived susceptibility, including knowledge of mother, feeding patterns and family income towards the nutritional status of children under five years old.
\end{abstract}

Keywords: family income, knowledge of mother, feeding patterns, nutritional status, children under five years

\section{Pendahuluan}

Gizi buruk merupakan masalah yang memerlukan penanganan secara serius. Gizi buruk akan berpengeruh terhadap kualitas sumber daya manusia (Krisnansari, 2010). Berk (2000) menyebutkan bahwa 40-60\% anak-anak di dunia tidak mendapatkan cukup pangan. Jumlah $g$

izi buruk dan kurang menurut hasil Riskesdas 2013 masih sebesar 19,6\% dibandingkan dengan target RPJMN sebesar $15 \%$ pada tahun 2014 dan terjadi peningkatan dibandingkan tahun 2010 (Kementrian Kesehatan RI, 2015). Anak yang kekurangan gizi akan berkembang lebih kecil. Pertumbuhan jaringan pada otak akan terpengaruh, yang akan berpengaruh dalam semua fungsi mental anak. Hal ini akan tampak pada usia sekolah dasar, di mana anak 
akan memiliki tingkat kecerdasan yang kurang, koordinasi sensori dan motoriknya sangat buruk, dan kelak akan memiliki kesulitan dalam berkonsentrasi di sekolah. Malnutrisi dapat diakibatkan oleh karena masukan makanan tidak memadai untuk memenuhi kebutuhan tubuh, atau dapat juga di akibatkan gangguan dari penyerapan makanan yang tidak cukup. Oleh karena penyediaan makanan, dan faktor-faktor emosi dapat juga membatasi masukan makanan. Kelainan metabolisme tertentu dapat pula menjadi penyebab malnutrisi (Sodikin, 2011). Menurut Nancy (2005) bahwa kekurangan gizi disebabkan oleh kekurangan asupan makanan yang kurang, yang disebabkan oleh tidak tersedianya makanan yang adekuat, anak tidak cukup mendapat makanan bergizi seimbang, dan pola makan yang salah. Arisman (2007) menyebutkan, ada empat faktor yang melatar belakangi terjadinya KKP, yaitu: masalah sosial, ekonomi, biologi, dan lingkungan. Kemiskinan, merupakan salah satu dari banyak determinan sosial-ekonomi. Kemiskinan merupakan sumber masalah paling dasar sebagai penyebab ketidak sediaan pangan, tempat tinggal yang padat serta kumuh, dan tidak sehat serta ketidak mampuan mengakses fasilitas kesehatan. Penelitian Kristanti \& Sari (2016) menyebutklan tidak ada perbedaan status gizi anak usia 4-6 tahun dari berat badan pada ibu bekerja dan ibu tidak bekerja.

Menurut Peraturan Menteri Kesehatan Republik Indonesia Nomor 23 tahun 2014 yang dimaksud pasal 20 tata laksana gizi buruk merupakan rangkaian tindakan yang bertujuan untuk perbaikan status gizi dengan prioritas menurunkan angka kematian pada balita gizi buruk. Berdasarkan rencana strategis program Diketorat Jenderal Bina Gizi dan KIA tahun 2015-2019, sasaran kegiatan perbaikan gizi masyarakat pada balita kurus yang mendapat makan tambahan adalah $70 \%$ (2015), 75\% (2016), 80\% (2017), 85\% (2018), dan 90\% (2019). Gizi yang baik akan menurunkan kesakitan, kecacatan, dan kematian sehingga meningkatkan kualitas sumber daya manusia (Kementerian Kesehatan Republik Indonesia, 2013).
Teori Health Belief Model menjelaskan ada beberapa faktor yang berhubungan dengan perilaku kesehatan seseorang dan biasanya digunakan untuk mengidentifikasi motivasi perilaku kesehatan dengan penyakit kronis seperti: kanker, HIV/AIDS, dan pencegahan merokok (Sulaeman, 2016). Kekurangan gizi dapat dikelompokkan dalam kategori penyakit kronis (Timmreck, 2001). Menurut Sulaeman (2016) konstruksi HBM meliputi : (a). Latar belakang, yaitu faktor sosio-demografi, seperti pendidikan, umur, jenis kelamin, suku, etnis; (b). Persepsi, meliputi: (i) ancaman (threat), yaitu kerentanan yang dirasakan (perceived susceptibility) atau menerima diagnosis, dan keparahan/keseriusan yang dirasakan (perceived severity/seriousility) dari keadaan sakit-kesehatan: (i) harapan (expectations), meliputi: manfaat/keuntungan yang dirasakan dari aksi (perceived benefits of action), hambatan yang dirasakan dari aksi (perceived barrier of action), dan efikasi diri yang diraskan untuk melakukan tindakan (perceived self-efficacy to perform action); (c) Pencetus asksi (cues to action), seperti media, pengaruh personal, dan pengingat, dan (d) Perilaku untuk mengurangi ancaman berbasis pada harapan (behavior to reduce threat based on exptations). Sementara itu persepsi yang dirasakan individu dipengaruhi oleh faktor modifikasi yang terdiri dari usia, jenis kelamin, ras/suku, motivasi, kepribadian, sosial ekonomi, dan tingkat pendidikan (Jones \& Bartlett, 2010). Perilaku/tindakan seseorang untuk mencegah atau mengobati penyakit juga dipengaruhi oleh petunjuk/pendorong untuk bertindak (cues to action) antara lain meliputi penyakit dari anggota keluarga (illness of a family member), laporan media (media reports) (Graham, 2002), kampanye media massa, saran dari orang lain, dan nasehat petugas kesehatan (Ali, 2002). Menurut Rosenstock et al., Health Belief Model menyebutkan bahwa perilaku dipengaruhi oleh latar belakang, persepsi dan pencetus aksi. Latar belakang yang dimaksud adalah faktor sosiedemografi seperti pendidikan, umur, jenis kelamin, ras, etknik, dan suku. Persepsi terdiri dari ancaman dan harapan, ancaman terdiri dari kerentanan yang dirasakan (menerima 
diagnosis) dan keparahan yang dirasakan dari keadaan sakit. Sedangkan faktor pencetus meliputi media, pengaruh individu dan pengingat.

Berdasarkan hasil pengumpulan data awal, menurut bidan desa bahwa pola pemberian makan pada sebagian anak usia diawah lima tahun lebih menekankan pada pemenuhan kebutuahn rasa lapar dan pengetahuan ibu untuk makanan yang memenuhi standar kebutuhan pertumbuhan dan perkembangan pada anak usia lima tahun masih rendah. Kurangnya pengetahuan dan pemahaman ibu akan kandungan karbohidrat, protein, vitamin, lemak dan mineral pada bahan makanan yang masih terbatas, yang mengakibatkan kurangnya kepedulian ibu dalam memberikan sumber makanan yang mengandung nilai gizi yang dibutuhkan anak pada usia dibawah lima tahun. Berdasarkan uraian diatas, maka peneliti tertarik untuk meneliti pengaruh pengetahuan ibu, pola pemberian makan, dan pendapatan keluarga terhadap status gizi anak dibawah usia lima tahun di Desa Pajerukan Kecamatan Kalibagor Kabupaten Banyumas dengan menggunakan pendekatan teori Health Belief Model. Tujuan penelitian ini adalah untuk Mengetahui hubungan pengetahuan ibu, pola pemberian makan, dan pendapatan keluarga terhadap status gizi anak usia di bawah lima tahun.

\section{Metode}

Penelitian ini menggunakan metode kuantitatif dengan desain penelitian cross sectional. Populasi ibu yang memiliki balita usia 3-5 tahun sebanyak 189 orang. Teknik pengumpulan sampel yang digunakan adalah simple random sampling, dengan jumlah 65 responden. Analisa data menggunakan uji chisqare.

\section{Hasil}

Berdasarkan hasil penelitian diketahui bahwa distribusi frekuensi karakteristik responden berdasarkan umur ibu, umur balita dan pendidikan dan distribusi pengetahuan ibu, pola pemberian makan, pendapatan keluarga dan status gizi balita menunjukan usia ibu balita berada pada rentang usia 21-35 tahun 38 (58.5\%). Untuk usia balita mayoritas berumur $36-48$ bulan 36 balita (55.38\%). Pendidikan orang tua balita mayoritas SD 29 (44,6\%), SMP 23 (35.4\%), SMA 8 (12.3\%) dan PT 5 (7.7\%). Pengetahuan ibu mayoritas baik 43 (66.2\%), kurang 22 (33.8\%). Sedangkan pola pemberian makan pada balita mayoritas kurang $37(56.9 \%)$ dan baik 28 (43.1\%). Pada status gizi mayoritas gizi baik $56(86.2 \%)$ dan gizi kurang 9 (13.8\%). Pendapatan keluarga mayoritas rendah 36 $(55.5 \%)$ dan pendapatan tinggi 29 (44.5\%). Berdasarkan hasil penelitian didapatkan usia sebagian besar subyek berada pada rentang usia 21-35 tahun sebanyak 38 (58.5\%).

Table 1. Hubungan antara Pengetahuan Ibu, Pola Pemberian Makan, Pendapatan Keluarga dengan Status gizi anak usia Dibawah Lima Tahun

\begin{tabular}{|c|c|c|c|c|c|}
\hline \multirow{2}{*}{ Indikator } & \multicolumn{2}{|c|}{ Jumlah } & \multirow{2}{*}{ Total n(\%) } & \multirow{2}{*}{ Rasio Prevalens (RP) } & \multirow{2}{*}{$P$-value } \\
\hline & baik $n(\%)$ & kurang $\mathrm{n}(\%)$ & & & \\
\hline \multicolumn{6}{|l|}{ Pengetahuan } \\
\hline Baik & $40(61,5)$ & $3(4,6)$ & $43(66,2)$ & $1.279(0.978-1.673)$ & $0.034 *$ \\
\hline Kurang & $16(24,6)$ & $(9,2)$ & $22(33,8)$ & & \\
\hline \multicolumn{6}{|c|}{ Pola pemberian makan } \\
\hline Baik & $33(50,8)$ & $1(1,5)$ & $34(52,3)$ & $1.308(1.054-1.623)$ & $0.008 *$ \\
\hline Kurang & $23(35,4)$ & $8(12,3)$ & $31(47,7)$ & & \\
\hline \multicolumn{6}{|l|}{ Pendapatan } \\
\hline Baik & $35(53,8)$ & $1(1,5)$ & $36(55,4)$ & $1.343(1.068-1.692)$ & $0.004 *$ \\
\hline Kurang & $21(32,3)$ & $8(12,3)$ & $29(44,6)$ & & \\
\hline Jumlah & $56(86,2)$ & $9(13,8)$ & $65(100)$ & & \\
\hline
\end{tabular}

Ket : *Signifikan pada $p$-value $0.044, \mathrm{n}=65$

Hasil penelitian menunjukan bahwa ada hubungan signifikan antara pengetahuan ibu dengan status gizi balita $p$-value 0.034 dan nilai Rasio Prevalens (RP) pada pengetahuan 
yaitu 1.279. Hal dapat diartikan responden dengan pengetahuannya baik memiliki 2 kali lebih baik status gizi balitanya. Untuk selang kepercayaanya [(0.978),(1.673)] dimana pada selang kepercayaan tidak mengandung nilai relatif risk 1 sehingga hanya menunjukkan adanya hubungan antara pengetahuan baik dengan status gizi yang baik. Variabel pola pemberian makan menunjukan ada hubungan yang signifikan dengan status gizi balita dengan nilai $p$ value 0.008 , dan nilai RP yaitu 1.308, untuk selang kepercayaanya [(1.054),(1.632)] dimana pada selang kepercayaan mengandung nilai relatif risk 1 . Pola pemberian makan memiliki faktor risiko 2 kali lebih besar untuk status gizi balita buruk.

Pada variabel pendapatan keluarga memiliki hubungan yang signifikan dengan status gizi balita nilai $p$-value 0.004 , nilai RP nya yaitu 1.343 , dengan selang kepercayaan [(1.065),(1.692)] dimana pada selang kepercayaannya juga mengandung nilai relatif risk 1 sehingga balita yang pendapatan keluarganya kurang memiliki faktor risiko 2 kali untuk terjadi status gizi buruk.

\section{Diskusi}

Usia responden menunjukan bahwa pada usia tersebut menunjukkan dalam usia yang matang dan dewasa. Lubis \& Pieter (2010) usia antara 21-35 tahun orang akan mencapai puncak kekuatan motorik dan merupakan masa penyesuaian diri terhadap kehidupan dan harapan sosial baru yang berperan sebagai orang tua. Usia ibu yang matang diharapkan kemampuan ibu tentang pengetahuan gizi anak akan baik. Sodikin (2012) ketidakadekuatan asupan makanan terhadap balita dipengaruhi oleh usia ibu, jarak kelahiran, dengan saudara kandung, penyakit infeksi, tingkat pendidikan keluarga, status pekerjaan ibu.

Berdasarkan hasil penelitian bahwa sebagian besar usia balita berada di usia 36-48 bulan sebanyak 36 (55.38\%). Pada usia tersebut merupakan usia yang rentan terhadap kebutuhan gizi karena masa balita merupakan masa transisi dari makanan bayi ke makanan dewasa. Menurut Marni (2014) balita merupakan kelompok umur yang rawan gizi dan penyakit, kelompok ini merupakan kelompok umur yang paling menderita akibat gizi dan jumlahnya dalam populasi besar. Beberapa anggapan yang menyebabkan anak balita ini rawan gizi dan rawan penyakit adalah balita sudah mulai main di tanah dan sudah dapat main diluar rumah sehingga lebih terpapar dengan lingkungan yang kotor dan kondisi yang memungkinkan untuk terinfeksi dengan berbagai macam penyakit. Penelitian Lestari (2016) menyebutkan terdapat hubungan signifikan antara usia dengan gizi kurang pada balita. Balita usia 22-36 bulan memiliki risiko 3,34 kali lebih besar mengalami gizi kurang dibandingkan dengan balita usia 37-59 bulan. Stanhope \& Lancester (2012) menjelaskan bahwa balita memiliki risiko biologi yang meliputi faktor genetik atau fisik ikut berperan dalam timbulnya risiko tertentu yang mengancam kesehatan. Usia balita yang masih muda menyebabkan sistem kekebalan tubuh yang belum berkembang. Hal ini menyebabkan balita lebih mudah terkena masalah nutrisi.

Berdasarkan hasil penelitian yang telah dilakukan pendidikan ibu masih rendah (SD \& SMP) menempati jumlah terbesar yaitu 52 (80\%). Dampak jenjang pendidikan yang rendah, adalah orang tua kurang memperhatikan pola makan terhadap balitanya karena kebanyakan orang tua lebih mengutamakan keinginan anaknya tanpa memperhatikan kebutuhan gizinya. Ada kecenderungan status gizi buruk dan status gizi kurang pada balita lebih banyak ditemukan pada ibu yang berpendidikan dasar (Junaidi, 2013).

Dapat dibuktikan dalam kuesioner pengetahuan ibu dengan item nomer 13 yang menyebutkan bahwa pada masa pertumbuhan anak balita membutuhkan nasi sebagai makanan pokoknya. Item tersebut merupakan jawaban yang benar sesuai dengan kunci karena nasi merupakan karbohidrat yang dapat digunakan untuk pemenuhan kebutuhan energi, pengatur metabolisme lemak dan berperan dalam sistem pencernaan namun $29.23 \%$ dari responden menjawab pertanyaan itu salah. Untuk kuesioner pola pemberian 
makan dengan nomer item 3 yang mengatakan bahwa menu makanan anak balita selalu diatur sesuai kebutuhan anak balitanya merupakan jawaban yang benar namun $40 \%$ dari responden menjawab salah, karena mereka mengutamakan keinginan anaknya tanpa memperhatikan kebutuhan gizi balitanya. Hal ini dapat disimpulkan bahwa pengetahuan ibu dan pola pemberian makan pada balita yang kurang baik akan mempengaruhi status gizi balita. Marni (2014) menyebutkan orang tua yang memiliki tingkat pendidikan yang tinggi akan lebih memahami makanan dan memilih makanan yang baik untuk anaknya. Pengetahuan dan ketrampilanya ibu akan lebih memperhatikan cara memasak, konsumsi anak, dan keragaman bahan makanan. Sodikin (2012) menjelaskan salah satu penyebab ketidadekuatan terhadap kebutuhan gizi balita adalah tingkat pendidikan keluarga. Mengacu konsep HBM dimana variabel demografi; umur, jenis kelamin, ras, etnis, dan pendidikan. HBM menunjukkan bahwa memodifikasi variabel akan mempengaruhi perilaku yang berhubungan dengan kesehatan secara tidak langsung dengan mempengaruhi presepsi keseriusan, kerentanan, manfaat, dan hambatan (Rosenstock, 1974; Glanz et al., 2008; cit., Sulaeman, 2016). Ancaman suatu penyakit dipersepsikan secara berbeda oleh setiap individu, termasuk dalam hal ini adalah status gizi balita.

Berdasarkan penelitian yang telah dilakukan menunjukan ada hubungan yang signifikan antara pengetahuan ibu dengan status gizi balita nilai $p$ value 0.034 . Hasil penelitian menunjukkan sebanyak $40(93 \%)$ memiliki pengetahuan baik. Tingkat pengetahuan yang baik erat kaitanya dengan pendidikan yang ditempuh oleh ibu. Pengetahuan yang baik akan menunjang terwujudnya pola perilaku yang baik pula. Pengetahuan tersebut memberikan dasar konseptual dan rasional bagi ibu dalam menentukan pola makan yang sesuai dengan kebutuhan gizi balitanya. Selain itu tingkat pendidikan sangat berpengaruh terhadap tingkat pengetahuan. Ibu yang mempunyai tingkat pendidikan yang lebih tinggi tentunya mempunyai pengetahuan yang lebih luas dan baik khususnya pengetahuan tentang pemberian nutrisi. Berdasarkan hasil penelitian sebagian besar ibu memiliki tingkat pendidikan rendah $52(80 \%)$ SD dan SMP. Menurut Mubarak dan Chayatin (2009) semakin tinggi pendidikan seseorang, maka semakin mudah menerima informasi, sebaliknya jika seseorang memiliki tingkat pendidikan yang rendah maka akan menghambat perkembangan sikap seseorang terhadap penerimaan informasi dan nilai-nilai baru. Notoatmodjo (2010) menerangkan bahwa pengetahuan adalah domain yang sangat penting untuk membentuk perilaku seseorang. Perilaku baru atau adopsi perilaku yang didasari oleh pengetahuan akan bersifat langgeng, sebaliknya apabila perilaku itu tidak didasari pengetahuan maka perilaku tersebut tidak akan berlangsung lama.

Berdasarkan penelitian menunjukkan ada hubungan yang signifikan antara pola pemberian makan dengan status gizi balita dengan nilai $p$-value 0.008 . Lebih lanjut penelitian ini memperoleh hasil balita dengan pola pemberian makan kurang dan status gizi kurang $8(21.6 \%)$. Pola makan balita yang kurang baik akan mempengaruhi status gizi. Beberapa alasan para orang tua yang anaknya masuk dalam kategori gizi bermasalah, karena ibu kurang menjaga kebersihannya saat mengolah makanan, tidak mencuci tangan sebelum melakukannya, selain itu para orang tua juga tidak membatasi anak jajana atau makan diluar. Kebersihan diri anak yang kurang, beberapa anak memiliki kuku panjang dan kotor, anak tidak mencuci tangan sebelum makan. Berdasarkan paparan di atas maka dapat disimpulkan bahwa jika pola pemberian makan baik makan status gizi balita baik, tetapi sebaliknya jika pola pemberian makan kurang baik maka kurang baik juga status gizi balita. Konsumsi makanan berpengaruh terhadap status gizi seseorang. Kondisi status gizi baik dapat dicapai bila tubuh memperoleh cukup zat-zat gizi yang akan digunakan secara efisien, sehingga memungkinkan terjadinya pertumbuhan fisik, perkembangan otak, kemampuan kerja untuk mencapai tingkat kesehatan optimal (Depkes RI, 2003). Menuru Martinah (2008) pola pemberian makan balita 
berpengaruh terhadap gizi buruk, sebab memuat kuantitas maupun kualitas pada tumbuh kembang balita menjadi kurang. Hasil penelitian berbeda ditemukan tidak ada hubungan yang bermakna antara pola pemberian makan dengan status gizi pada balita (Junaidi, 2013).

Berdasarkan penelitian yang telah dilakukan menunjukan terdapat hubungan yang signifikan antara pendapatan keluarga dengan status gizi balita dengan nilai pvalue 0.004. Pada penelitian ini ditemukan pendapatan rendah dengan status gizi kurang baik sebanyak 8 (12.3\%). Pendapatan berpengaruh terhadap konsumsi makanan sehari-hari. Apabila pendapatan rendah maka makanan yang dikonsumsi tidak mempertimbangkan nilai gizi, tetapi nilai materi lebih menjadi pertimbangan selain itu dimana sebagian besar keluarga bekerja dalam sektor transportasi. Supariasa, Bakri, dan Fajar (2002) yang menyebutkan bahwa pendapatan keluarga mempengaruhi pola makan, proporsi anak yang mengalami gizi kurang berbanding terbalik dengan pendapatan keluarga. Semakin kecil pendapatan penduduk semakin tinggi prosentase anak yang kekurangan gizi. Masyitha (2011) ada hubungan antara status ekonomi keluarga dengan status gizi balita, karena semakin rendah status ekonomi keluarga semakin buruk status gizi balita. Sodikin (2012) kemiskinan merupakan salah satu dari determianan sosial-ekonomi. Kemiskinan merupakan sumber masalah paling dasar sebagai ketidak-tersediaan pangan, tempat tinggal yang padat, kumuh, dan tidak sehat, serta ketidakmampuan mengakses fasilitas layanan kesehatan.

Perilaku ibu dalam pencegahan gizi buruk balita tidak dipengaruhi secara langsung oleh penghasilan dan motivasi ibu akan tetapi dipengaruhi melalui faktor lain seperti perasaan terancam akan kesehatan balita mereka, persepsi manfaat yang diperoleh dan hambatan yang dihadapi, persepsi akan kemampuan diri dan dukungan dari keluarga (Fauziah, Djuari, \& Arief, 2015; Walker, at al, 2006) tingginya keuntungan yang dipersepsikan dari perilaku pemenuhan gizi sesuai kebutuhan berhubungan dengan komitmen untuk melakukan perilaku tersebut. Sesuai dengan pendapat tersebut maka semakin positif persepsi ibu tentang kemanfaatan melakukan tindakan pencegahan gizi buruk, maka akan semakin kuat komitmenya terhadap perilaku tersebut.

\section{Simpulan}

Usia responden pada rentang 21-35 tahun 38 (58.5\%). Usia balita antara 36-48 bulan sebanyak 36 (55.38\%), pendidikan orang tua mayoritas SD-SMP 52 (20\%). Modifing factors yang berhubungan dengan status gizi anak dibawah usia lima tahun adalah pengetahuan $(p=0.034)$, pola pemberian $(p=0.008)$, dan pendapatan $(p=$ $0.004)$.

\section{Daftar pustaka}

Ali, N. S. (2002). Prediction of coronay heart disease preventive behaviors in women: a test of the health belief model. Women \& Health, 35(1), 83-96.

Arisman. (2007). Buku Ajar Ilmu Gizi, Gizi dalam Daur Kehidupan. Jakarta: EGC.

Berk, L. E. (2000). Child Develompent. $5^{\text {th }}$ Ed. Massachusetts: Allyn \& Bacon..

Depkes RI. (2003). Pedoman Penilaian Pertumbuhan Anak. Jakarta: Depkes RI

Fauziah, N. I, Djuari, L., \& Arief, S. Y. (2015). Pengembangan model perilaku ibu dalam pencegahan gizi buruk. Jurnal Ners, 10(2), 195-200.

Graham, M. E. (2002). Health beliefs and self breast examination in black women. Journal of Cultural Diversity. 9(2), 4954.

Jones \& Bartlett. (2010). Health Belief Model. Chapter 4. Diakses 17 Maret 2018. http://www.jblearning.com/samples/076 3743836/chapter\%204.pdf

Junaidi. (2013). Faktor-faktor yang berhubungan dengan status gizi balita di taman kanak-kanak Nurul Huda Kecamatan Indra Jaya Kabupaten Pidie 2012. Sains Riset, 3(1), 1-11.

Kementerian Kesehatan Republik Indonesia. (2013). Pusat Data dan Informasi Profil Kesehatan Indonesia 2012. Jakarta: Kementerian Kesehatan RI. 
Kementerian Kesehatan Republik Indonesia. (2015). Infodatin Pusat Data dan Informasi Kementrian Kesehatan RI. Jakarta: Kementrian Kesehatan RI.

Kristanti, E. E \& Sari, W. K. A. D. (2016). Perbedaan staus gizi anak pada ibu bekerja dan ibu tidak bekerja. Jurnal Stikes, 9(2), 183-145.

Krisnansari, D. (2010). Nutrisi dan gizi buruk. Mandala of Health, 4(1), 60-68 .

Lestari, D. N. (2016). Analisis determinan gizi kurang pada balita di Kulon Progo, Yogyakarta. Indonesia Journal of Nursing Practices. 1(1), 15-21.

Marni. (2014). Buku ajar keperawatan pada anak dengan gangguan pernapasan. Yogyakarta: Gosyen Publishing.

Martinah. (2008). Gizi buruk dan tanggung jawab pemerintah. Jakarta: FK-UI

Masyitha. (2011). Hubungan antara status ekonomi dengan status gizi balita di Desa Sarirogo Kecamatan Sidoarjo Kabupaten Sidoarjo. Karya Tulis Ilmiah. STIKES YARSIS Surabaya.

Stanhope, M. \& Lancaster, J. (2012). Public Health Nursing Population Centered Health Care in The Community. $8^{\text {th }}$ ed. Missouri: Elsevier.

Supariasa, I. D. N., Bakri, B, \& Fajar, I. (2002). Penentuan status gizi. Jakarta: EGC.

Timmreck, T. C. (2001). Managing motivation and developing job satisfaction in the
Mubarak, W. I., dan Chayatin, N. (2009). Ilmu kesehatan masyarakat teori dan aplikasi. Salemba Medika: Jakarta.

Nancy, Y. (2005). Pedoman umum gizi seimbang. Jakarta: Gramedia Pustaka Utama.

Notoatmodjo. S. (2010). Metodologi penelitian kesehatan. Jakarta: Rineka Cipta.

Peraturan Menteri Kesehatan Republik Indonesia. (2014). Upaya perbaikan gizi. Jakarta: Depkes RI.

Pieter, H. Z. \& Lubis, N. L. (2010). Pengantar psikologi dalam keperawatan. Jakarta: Kencana.

Sulaeman, S. E. (2016). Pembelajaran dan teori perilaku kesehatan: Konsep dan aplikasi. Solo: UPT UNS Press.

Sodikin. (2011). Asuhan keperawatan anak gangguan sistem gastrointestinal dan hepatobilier. Jakarta: Salemba Medika.

Sodikin. (2012). Keperawatan anak gangguan pencernaan. Jakarta: EGC.

health care work environment. The Health Care Manager, 20(1), 42-58.

Walker, S., Pullen, C., Hertzog, M., Broekner, L., \& Hageman, P. (2006). Determinants of older rural women's activity and eating. Western Journal of Nursing Research, 449-474. 